\title{
Occurrence of Extended-Spectrum Beta- Lactamases (ESBLS) Producing Enterobacteria in Animal Products and their Environment
}

\author{
Akanksha Yadav ${ }^{1}$, Namita Joshi ${ }^{1}$ * and R.K. Joshi ${ }^{2}$ \\ ${ }^{1}$ Department of Veterinary Public Health and Epidemiology, ${ }^{2}$ Department of Veterinary \\ Microbiology, College of Veterinary Science and Animal Husbandry, N.D. University of \\ Agriculture and Technology, Kumarganj-224229, Faizabad (UP), India \\ *Corresponding author
}

\begin{tabular}{|c|}
\hline Keywords \\
\hline $\begin{array}{l}\text { ESBL, } \\
\text { Enterobacteria, } \\
\text { Milk, Meat, } \\
\text { Environment }\end{array}$ \\
\hline Article Info \\
\hline $\begin{array}{l}\text { Accepted: } \\
\text { 18 April } 2019 \\
\text { Available Online } \\
10 \text { May } 2019\end{array}$ \\
\hline
\end{tabular}

\section{A B S T R A C T}

The present study was undertaken to evaluate the status of ESBL producing Enterobacteriaceae in foods of animal origin and their environment. A total of 125 samples were collected comprising 95 animal products ( 40 raw milk, 25 milk products, 15 raw meat and 15 meat products) and 30 environmental samples. The isolation rate was recorded $93.95 \%$ in food samples with Citrobacter (38.41\%) being the dominant flora, while $100 \%$ in environmental samples with the dominance of E. coli $(89.18 \%)$. Of all the ESBL producers, $24.29 \%$ were found positive by phenotypic method while $16.38 \%$ were found positive by PCR. The phenotypic test revealed highest occurrence of ESBL producers in environmental samples $(56.76 \%)$ followed by milk $(24.44 \%)$, meat $(16.0 \%)$, meat products $(15.0 \%)$ and milk products $(8.00 \%)$. Similarly, PCR assay also recorded highest occurrence in the environment $(48.65 \%)$ followed by raw meat $(8.0 \%)$ and raw milk $(2.0 \%)$ samples; however none of the ESBL genes was detected in milk and meat products. ESBL genes positive isolates belonged to the genera Escherichia, Klebsiella and Citrobacter. The frequency of $b l a_{\mathrm{CTX}}, b l a_{\mathrm{SHV}}$ and $b l a_{\mathrm{TEM}}$ genes in $E$. coli isolates was $37.97 \%, 6.89 \%$ and $3.44 \%$, respectively. The co-existence of $b l a_{\mathrm{CTX}}$ and $b l a_{\mathrm{TEM}}, b l a_{\mathrm{SHV}}$ and $b l a_{\mathrm{TEM}}$ and $b l a_{\mathrm{CTX}}$ and $b l a_{\mathrm{SHV}}$, was found $17.24 \%, 6.89 \%$ and $3.44 \%$ in E. coli isolates, respectively. Citrobacter isolates harboured single (bla $a_{\text {Стх }} 3.44 \%$ ) as well as multiple genes $\left(b l a_{\mathrm{CTX}}+b l a_{\mathrm{SHV}} 3.44 \%\right)$ and $\left(b l a_{\mathrm{CTX}} b l a_{\mathrm{TEM}} 6.89 \%\right)$ while Klebsiella isolates showed only bla $a_{\text {СтХ }}$ gene $(6.89 \%)$. Only one E. coli isolate (3.44\%) in the present study harboured all three genes.

\section{Introduction}

ESBLs are the rapidly evolving $\beta$-lactamases (Paterson and Bonomo, 2005) with an ability to hydrolyze penicillins, first, second, and third generation cephalosporin, and aztreonam but can be inhibited by $\beta$-lactamase inhibitors such as clavulanic acid (Jacoby and Medeiros, 1991; Bush et al., 1995). The extensive use of such antibiotics in food animals has resulted in the development of resistance and food animal serve as a reservoir of resistant strains for human and animal population. Food may get contaminated with these strains during 
animal slaughtering, milking or processing. Consequently, without good hygienic practices, foods may act as a vehicle for transfer of $\beta$-lactam resistant bacteria to the consumers (Overdevest et al., 2011). Some recent studies have documented frequent occurrence of ESBL producers in poultry (Kolar et al., 2010; Overdevest et al., 2011), dairy and meat products (Gundogan and Yakar, 2007; Gundogan et al., 2011). Due to paucity of data from this region of UP, the present study aimed to assess the occurrence of ESBL-producing enterobacteria in milk, meat and their products as well as farm animal's environment.

\section{Materials and Methods}

\section{Samples Collection}

A total of 125 samples from food animal and their environment were collected in the present study. The food samples comprising of raw milk (40), milk products (30), raw meat (15) and meat products (15) were collected from different shops of Kumarganj and Lucknow (UP). Processed milk product's samples included ice cream, dahi, chhena, paneer, rasgulla, peda and barfi; while meat product's samples included beef kabab, mutton kabab, chicken tikka, chicken roll, biryani and roasted chicken. Raw milk samples were also procured from instructional livestock farming complex (I.L.F.C.), Teaching veterinary clinical complex (T.V.C.C.) of College of Veterinary Science \& Animal Husbandry, animal farms nearby Kumarganj.

Samples were collected aseptically and transported under refrigerated condition to the laboratory. Total 30 environmental samples which included floor swabs representing the animal farm environment were collected from I.L.F.C. and animal farms nearby Kumarganj, U.P.

\section{Isolation and identification of Enterobacteria}

The samples were processed for isolation of Enterobacteria as per the procedures described by Cruickshank et al., (1975). Mac Conkey Lactose Agar, Eosin Methylene Blue Agar and Brilliant Green Agar media were used for isolation as well as differentiation of lactose fermenters and lactose non-fermentors belonging to Enterobacteriacae. All the samples diluted in peptone water were grown in improvised media i.e. MacC-CTX broth and MacC-CTX agar to selectively culture the drug resistance organism and eliminate the susceptible organism so as to minimise the growth of all other organism. The identification of enterobacteria was done on the basis of morphology, growth and biochemical characteristics as per the method described by Edwards and Ewing (1972). The biochemical tests included catalase, oxidase, indole, methyl red, Voges Proskauer, citrate, urease, triple sugar iron agar and sugar fermentation tests.

\section{Identification of ESBL producers}

Screening of ESBL producing isolates of Enterobacteriaceae was done by disk diffusion method as prescribed in CLSI guidelines (2009). The isolates were tested against two antibiotics viz. cefotaxim and ceftazidime and presumed as ESBL producers if the zone diameter for cefotaxim was $\leq 27$ $\mathrm{mm}$ and for ceftazidime $\leq 22 \mathrm{~mm}$. These ESBL producing Enterobacteria were confirmed by combination disks test as per the procedure of CLSI (2009) with slight modification. The ESBL kit I and kit III of Hi media Laboratories were used for phenotypic confirmation of ESBL producers as per the manufacturer's instruction. The test organisms were considered as ESBL positive if a $\geq 5 \mathrm{~mm}$ increase in zone diameter was observed for two or more antimicrobial agents 
tested in combination with clavulanic acid versus its zone when tested alone.

\section{Molecular characterization of ESBL producers}

The ESBL genes were targeted for molecular characterization of ESBL producers using published primer sequence (Table 1) synthesized by Bangalore Genei (India). The DNA templates were prepared using snapchill method as described by Franco et al., (2008). The PCR assay was performed in 20 $\mu \mathrm{l}$ final volume containing $10 \mu \mathrm{l}$ of master mix, $2 \mu 1$ of forward and reverse primer (100pmol), $2 \mu \mathrm{l}$ of $\mathrm{MgCl}_{2}, 2 \mu \mathrm{l}$ of DNA template and $2 \mu 1$ of nuclease free water. The ESBL genes viz. bla тем, bla СтХ-м and bla SHV were targeted by PCR using the conditions given in the table 2. The amplified PCR products were run in $1.5 \%$ agarose gel and visualized and analyzed using gel documentation system (Uvi tech, UK).

\section{Results and Discussion}

Food animals are increasingly being recognized as a reservoir for ESBL-producing strains. Worldwide studies have revealed that ESBL producing isolates such as E. coli and Klebsiella can contaminate foods of animal origin and contribute to diseases and spoilage (Gundogan and Yakar, 2007; Haryani et al., 2007). In the present study, processing of 125 samples yielded 186 isolates, of which 177 (95\%) were screened out as members of Enterobacteriaceae family. The isolates grew luxuriantly and selectively on MLA showing typical morphology. The small round rose pink colonies were regarded as of $E$. coli and Citrobacter, while the light pink mucoid colonies were regarded as of Enterobacter and Klebsiella. The pale colourless colonies on MLA were presumed as of Salmonella and Proteus. Further identification and differentiation of enterobacteria was done using selective medium like EMB and BGA. The tiny metallic sheen colonies on EMB were considered as $E$. coli, while purple dark centred colonies with mucoid rim were regarded as either Enterobacter or Klebsiella; however, the colonies of Klebsiella appeared smaller than Enterobacter. The lactose nonfermenters isolates were grown on BGA and the isolates revealing light pinkish colonies with dark pinkish background of the media were presumed as Salmonella. The isolates showing swarming characteristic on nutrient agar plates were considered as Proteus. Further identification and differentiation of bacterial isolates was done on the basis of motility, staining and biochemical characteristics. Based on these characteristics, 68 isolates were identified as Citrobacter spp., 54 isolates as E. coli, 30 isolates as Enterobacter spp., 15 isolates as Klebsiella spp., 6 isolates as Salmonella and 4 isolates as Proteus spp (Table 1). Isolation rate of enterobacteria was found to be $100 \%$ from environmental samples and raw meat samples, while raw milk, milk products and meat products revealed $97.82 \%, 89.28 \%$, $90.90 \%$ isolation rate, respectively (Table 2 ). Thus overall isolation rate of enterobacteria from foods of animal origin was found to be $93.95 \%$.

The enterobacterial isolates were subjected to ESBL screening using cefotaxime in growth medium and all the presumptively positive ESBL producers were further confirmed by phenotypic double disc diffusion assay. The highest prevalence of ESBL producers was seen in environmental samples $(56.76 \%)$ followed by milk (24.44\%) and milk products $(8.0 \%)$, meat $(16.0 \%)$ and meat products (15.0\%). PCR assay recorded highest prevalence $(48.65 \%)$ in the environment samples followed by raw meat $(8.0 \%)$, raw milk samples (2.0\%). None of the isolates from milk and meat products revealed ESBL genes (Table 2). All the enterobacterial 
isolates tested positive for ESBL genes belonged to 3 different genera viz. Escherichia, Citrobacter and Klebsiella. Proportionate study of ESBL and Non-ESBL producers among the enterobacterial isolates revealed highest distribution rate in $E$. coli (74.91\%) followed by Klebsiella (15.38\%), Citrobacter (6.25\%). However, rest of the enterobacteria i.e. Enterobacter, Salmonella and Proteus were found to be non-ESBL producers. Source wise distribution study revealed that $E$. coli were found in highest proportion in environmental isolates $(55.17 \%$, 16) followed by raw milk $(17.24 \%, 5)$ and raw meat isolates $(6.90 \%$, 2). All 4 ESBL positive Citrobacter were isolated from raw milk with $13.79 \%$ prevalence while 2 ESBL positive Klebsiella isolates were recovered from the environment with $6.89 \%$ prevalence. However, none of the ESBL positive E. coli, Citrobacter and Klebsiella could be recovered from milk and meat products.

The distribution study of ESBL genes (Fig. 1, 2 and 3) among enterobacterial isolates revealed that out of 29, occurrence of ESBL genes was highest in E. coli $(12.99 \%, 23)$, followed by Citrobacter $(2.25 \%, 4)$ and Klebsiella $(1.12 \%, 2)$. Among E. coli isolates, $b l a_{\text {CTX }}$ gene $(37.93 \%)$ was predominantly present followed by bla $\mathrm{SHV}(6.89 \%)$ and $b l a_{\mathrm{TEM}}(3.44 \%)$. The co-existence of $b l a_{\mathrm{CTX}}$ with $b l a_{\text {TEM }}$ and $b l a_{\mathrm{SHV}}$ was recorded in $5(17.24 \%)$ isolates and 1(3.44\%) isolate, respectively. The $b l a_{\mathrm{SHV}}$ and $b l a_{\mathrm{TEM}}$ gene combination was detected in 2 isolates with $6.89 \%$ prevalence. Only one isolate of $E$. coli carried all the three genes with $3.44 \%$ prevalence. The frequency rate of ESBL genes in Citrobacter was found to be $3.44 \%$, $3.44 \%$ and $6.89 \%$ for bla $a_{\text {СTX }}$, bla $a_{\text {СтX }}$ and $b l a_{\mathrm{TEM}}, b l a_{\mathrm{CTX}}$ and $b l a_{\mathrm{SHV}}$, respectively. In ESBL positive Klebsiella isolates, only bla $a_{\text {СTX }}$ gene was detected with $6.89 \%$ prevalence (Table 3). None of the isolates of Enterobacter, Salmonella or Proteus were found positive for ESBL genes.
Foods may act as a vehicle for transfer of $\beta$ lactam resistant bacteria to the consumers without good hygienic practices (Overdevest et al., 2011). The present study was conducted with the aim to assess the occurrence of ESBL-producing enterobacteria in different types of foods of animal origin sold out in retail market in UP as well as in their environment. The overall isolation rate of enterobacteria from foods of animal origin was found to be $93.95 \%$ while all the environmental samples $(100 \%)$ were found to harbour enterobacteria. Our finding corroborated with the observation of Tham et al., (2012) where $82.7 \%$ food sample swabs exhibited characteristic growth of enterobacteria while Khan et al., (2015) reported $51.85 \%$ occurrence of enterobacteria in food items from Karanchi. However, Geser et al., (2012) reported that no ESBL producing enterobacteria could be isolated from foods of animal origin from Switzerland. These geographic differences may be attributed to variation in hygienic standards. Among the various food products analysed in present study, isolation rate of enterobacteria was $97.82 \%, 89.28 \%, 100 \%$ and $90.90 \%$ in raw milk, milk products, raw meat and meat products, respectively. Of 177 isolated strains of the family Enterobacteriaceae, the dominant bacterial flora was Citrobacter (38.41\%) followed by E. coli $(30.50 \%)$, Enterobacter (16.94\%), Klebsiella (8.47\%), Salmonella (3.38\%) and Proteus (2.25\%). Enterobacteriaceae contamination observed in this study clearly highlights breakdown of hygienic handling practices at different stages of the production, processing and distribution chain. Our findings were in conformity with the observations of Fadel and Ismail (2009) and Saikia and Joshi (2010) who also reported enterobacteria in most of the milk products and meat products, respectively. Likewise, Yusha et al., (2010) also reported Citrobacter as predominant organisms $(31.25 \%)$ in food. However, Shahid et al., (2009) reported 
Citrobacter as second most dominant organism from food specimens (meat and milk products) sold out in Indian markets. In most of the studies carried out on animal food products, the dominant bacterial flora appeared to be either E. coli (Jensen et al., 2006; Kumar et al., 2011; Tekiner et al., 2015) or Klebsiella (Kim et al., 2005; Shahid et al., 2009; Gundogan and Avci, 2013). The reason behind could be that these are common inhabitants of gastrointestinal tract and most widely distributed environmental contaminants. In environmental swab samples, E. coli was the most dominant organism $(89.18 \%)$ followed by Enterobacter $(5.40 \%)$ and Klebsiella $(5.40 \%)$ which coincided with the observations of Mesa et al., (2006).

All the presumptive ESBL enterobacterial isolates were subjected to double disc diffusion assay for phenotypic confirmation. The highest occurrence of ESBL producers was seen in environmental samples $(56.76 \%)$ followed by milk $(24.44 \%)$, meat $(16 \%)$, and meat products $(15 \%)$ and milk products $(8 \%)$. Similarly, Mesa et al., (2006) also recorded the highest prevalence of ESBL producers in farm samples (80-100\%) as compared to food samples $(0.40 \%)$ by E-test. Polymerase chain reaction characterized merely 29 isolates as ESBL producers and majority were recorded in environment samples $(48.65 \%)$ followed by raw meat $(8.0 \%)$ and raw milk $(2.0 \%)$. Likewise, Gundagon and Avci (2013) tested presence of ESBL producers in animal foods and reported more number of ESBL producers from meat products than milk and milk products. The relatively high occurrence of ESBL producers in floor samples is not surprising as there is indiscriminate use of antibiotics in veterinary practices, and non ESBL producers may acquire the plasmid from ESBL producers living in the same environment. Moreover, it is striking that none of the ESBL was found in milk products and meat products. The non occurrence of ESBL producers in milk and meat products in our study might be attributed to high processing temperature and low moisture content of these products. Present findings were found in agreement with the observations of Geser et al., (2012) as $26.9 \%$ fecal samples of farm animals yielded ESBL and only $1.5 \%$ mastitic milk isolates were found ESBL producers but none was isolated from either minced meat or bulk tank milk samples. The relatively high occurence of ESBL in raw milk than raw meat in our study might be attributed to mastitic milk samples from the animals undergoing treatment.

In the present study, the frequency of ESBL producing E. coli (79.31) was highest as compared to other enterobacteria (Citrobacter, $13.79 \%$ and Klebsiella, 6.89 $\%$ ), which was similar to those reported by Tekiner et al., (2015) where the most prevalent ESBL producer was E. coli (44 of 55), followed by six Citrobacter spp., five Enterobacter and 2 Klebsiella. Similar pattern of observations was reported by various coworkers from different parts of the world (Mesa et al., 2006; Geser et al., 2012 and Gondagon and Avci, 2013). The proportionate study revealed that approximately half of the E. coli $(42.59 \%)$ isolates were ESBL producers while majority of the isolates of Citrobacter $(94.12 \%)$ and Klebsiella $(86.66 \%)$ were non ESBL producers. There are evidences reporting an increase in prevalence of ESBL-producing $E$. coli in foods (Duan et al., 2006; Coque et al., 2008, Hiroi et al., 2012). ESBL-producing E. coli associated mortality is three-times higher than non ESBL producing E. coli (Melzera and Petersen, 2007).

Genotypic analysis in the present study, showed that the ESBL genes carrying isolates belonged to only 3 genera of family Enterobacteriaceae i.e. Escherichia, 
Citrobacter and Klebsiella. These isolates carried bla genes alone as well as in combination. The maximum number of $E$. coli isolates harboured ESBL genes with predominance of $b l a_{\mathrm{CTX}}$ gene $(37.93 \%)$ followed by bla $a_{\mathrm{SHV}}(6.89 \%)$ and $b l a_{\mathrm{TEM}}$ (3.44\%). Similarly, Le et al., (2015) also reported that approximately $40 \%$ of the ESBL $E$. coli isolates belonged exclusively to the CTX-M group and only $3.5 \%$ belonged to the TEM group. Whereas, Tekiner et al., (2015) reported predominance of $b l a_{\text {TEM }}$ genes followed by bla $a_{\mathrm{CTX}}$ and bla $a_{\mathrm{SHV}}$ in $E$. coli. Some of E. coli isolates in the present study showed co-existence of $b l a_{\mathrm{CTX}}$ and $b l a_{\mathrm{TEM}}$ $(17.24 \%), b l a_{\mathrm{CTX}}$ and $b l a_{\mathrm{SHV}}(3.44 \%), b l a_{\mathrm{SHV}}$ and $b l a$ TEM $(6.89 \%)$ and only one isolate (3.44\%) exhibited multiple genes. These findings were in accordance with the observations of Tekiner et al., (2015). Citrobacter obtained in the present study also exhibited predominance of bla $_{\mathrm{CTX}}$ gene distributed either alone $(3.44 \%)$ or in combination with $b l a_{\mathrm{SHV}}(6.89 \%)$ and $b l a_{\mathrm{TEM}}$ (3.44\%). Likewise, Shahid et al., (2009) also found majority of Citrobacter harbouring $b l a_{\text {СTX-M }}$ gene $(67.5 \%)$ followed by bla $(40 \%)$ and bla $a_{\mathrm{SHV}}$ gene $(25 \%)$.

On the contrary, Tekiner et al., (2015) reported predominance of $b l a_{\mathrm{TEM}}$ gene $(7.3 \%)$ in Citrobacter isolates with co-existence of $b l a_{\mathrm{TEM}}$ and $b l a_{\mathrm{SHV}}$ genes in $5.5 \%$ isolates. The $b l a_{\text {СтX }}$ gene $(6.89 \%)$ was also dominant in Klebsiella isolates obtained in the present study as none of the other gene was detected. Similar to our finding, previous workers have also reported the predominance of bla $a_{\mathrm{CTX}}$ gene in Klebsiella isolated from different sources (Hiroi et al., 2011; Tekiner et al., 2015) (Table 4 and 5).

Table.1 Primers sequence used for identification of ESBL genes

\begin{tabular}{|c|c|c|c|}
\hline Gene & Sequence & Product size & Reference \\
\hline bla $_{\mathrm{TEM}}$ & $\begin{array}{l}\text { F-ATGAGTATTCAACATTTCCG } \\
\text { R-TTAATCAGTGAGGCACCTAT }\end{array}$ & $851 b p$ & $\begin{array}{l}\text { Grimm et al., } \\
2004\end{array}$ \\
\hline$b^{b l a} a_{\text {CTХ }}$ & $\begin{array}{l}\text { F-CGCTTTGCGATGTGCAG } \\
\text { R-ACCGCGATATCGTTGGT }\end{array}$ & $551 \mathrm{bp}$ & $\begin{array}{l}\text { Paterson et al., } \\
2003\end{array}$ \\
\hline$b l a_{\mathrm{SHV}}$ & $\begin{array}{l}\text { F-GCAAAACGCCGGGTTATTC } \\
\text { R-CGTTAGCGTTGCCAGTGCT }\end{array}$ & 940bp & $\begin{array}{l}\text { Grobner et al., } \\
2009\end{array}$ \\
\hline
\end{tabular}

Table.2 PCR cycling conditions used for ESBL gene amplification

\begin{tabular}{|c|c|c|c|}
\hline Parameters & $\begin{array}{c}\boldsymbol{b l a}_{\mathrm{TEM}} \\
\text { (temp,time) }\end{array}$ & $\begin{array}{c}\boldsymbol{b l a}_{\mathrm{CTX}-\mathrm{M}} \\
(\mathbf{t e m p}, \text { time })\end{array}$ & $\begin{array}{c}\boldsymbol{b l a}_{\mathbf{S H V}} \\
\text { (temp,time) }\end{array}$ \\
\hline $\begin{array}{c}\text { Initial } \\
\text { denaturation }\end{array}$ & $94^{\circ} \mathrm{C}, 5 \mathrm{~min}$. & $94^{\circ} \mathrm{C}, 5 \mathrm{~min}$. & $95^{\circ} \mathrm{C}, 5 \mathrm{~min}$. \\
\hline Number of cycle & 35 & 35 & 35 \\
\hline Denaturation & $94^{\circ} \mathrm{C}, 30 \mathrm{sec}$. & $94^{\circ} \mathrm{C}, 30 \mathrm{sec}$. & $94^{\circ} \mathrm{C}, 30 \mathrm{sec}$. \\
\hline Annealing & $50^{\circ} \mathrm{C}, 35 \mathrm{sec}$ & $55^{\circ} \mathrm{C}, 35 \mathrm{sec}$ & $58^{\circ} \mathrm{C}, 40 \mathrm{sec}$ \\
\hline Elongation & $72^{\circ} \mathrm{C}, 40 \mathrm{sec}$. & $72^{\circ} \mathrm{C}, 40 \mathrm{sec}$. & $72^{\circ} \mathrm{C}, 45 \mathrm{sec}$. \\
\hline Final extension & $72^{\circ} \mathrm{C}, 5 \mathrm{~min}$. & $72^{\circ} \mathrm{C}, 5 \mathrm{~min}$. & $72^{\circ} \mathrm{C}, 5 \mathrm{~min}$. \\
\hline Final Hold & $10^{\circ} \mathrm{C}, 5 \mathrm{~min}$. & $10^{\circ} \mathrm{C}, 5 \mathrm{~min}$. & $10^{\circ} \mathrm{C}, 5 \mathrm{~min}$. \\
\hline
\end{tabular}


Table.3 Isolation rate of Enterobacteria in various animal products and their environment

\begin{tabular}{|c|c|c|c|c|c|c|}
\hline $\begin{array}{c}\text { Sources } \\
\left(\mathrm{n}=\begin{array}{c}\text { Enterobacterial isolates } \\
\text { number })\end{array}\right.\end{array}$ & 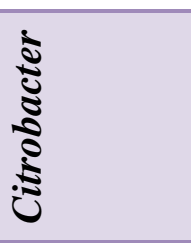 & $\begin{array}{l}\tilde{\Xi} \\
\dot{\Xi}\end{array}$ & 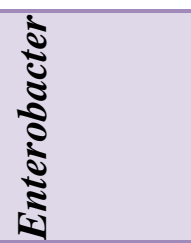 & 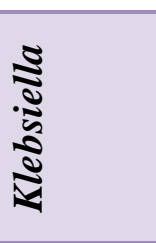 & 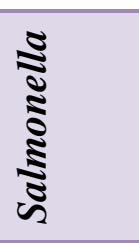 & 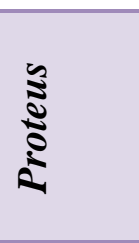 \\
\hline & $\mathrm{N}(\%)$ & $\mathrm{N}(\%)$ & $\mathrm{N}(\%)$ & $\mathrm{N}(\%)$ & $\mathrm{N}(\%)$ & $\mathrm{N}(\%)$ \\
\hline Raw Milk n=45 & $18(40)$ & $10(22.22)$ & $11(24.44)$ & $4(8.88)$ & $1(2.22)$ & $1(2.22)$ \\
\hline Milk Products $n=50$ & $29(58.00)$ & $4(8.00)$ & $8(16.00)$ & $5(10.00)$ & $2(4.00)$ & $2(4.00)$ \\
\hline Raw Meat $n=25$ & $12(48.00)$ & $3(12.00)$ & $5(20.00)$ & $2(8.00)$ & $2(8.00)$ & $1(4.00)$ \\
\hline Meat Products $n=20$ & $9(45.00)$ & $4(20.00)$ & $4(20.00)$ & $2(10.00)$ & $1(5.00)$ & Nil \\
\hline Environment $\mathbf{n}=\mathbf{3 7}$ & Nil & $33(89.18)$ & $2(5.40)$ & $2(5.40)$ & Nil & Nil \\
\hline Total $=177$ & $68(38.41)$ & $54(30.50)$ & $30(16.94)$ & $15(8.47)$ & $6(3.38)$ & $4(2.25)$ \\
\hline
\end{tabular}

Table.4 Prevalence of ESBL Enterobacteria in animal foods and their environment

\begin{tabular}{|c|c|c|c|}
\hline $\begin{array}{c}\text { Source } \\
(\mathbf{n}=\text { no. of isolates) }\end{array}$ & Enterobacteria & \multicolumn{2}{|c|}{ ESBL positive isolates } \\
\cline { 3 - 4 } Raw Milk n=46 & $45(97.82 \%)$ & $11(24.44 \%)$ & $9(2.0 \%)$ \\
\hline Milk Products n=56 & $50(89.28 \%)$ & $4(8.0 \%)$ & Nil \\
\hline Raw Meat $\mathbf{n = 2 5}$ & $25(100 \%)$ & $4(16.0 \%)$ & $2(8.0 \%)$ \\
\hline Meat Products n=22 & $20(90.90 \%)$ & $3(15.0 \%)$ & Nil \\
\hline Environment $\mathbf{n = 3 7}$ & $37(100 \%)$ & $21(56.76 \%)$ & $18(48.65 \%)$ \\
\hline Total $(\mathbf{n = 1 8 6})$ & $177(95.16 \%)$ & $43(24.29 \%)$ & $29(16.38 \%)$ \\
\hline
\end{tabular}

Table.5 Distribution of ESBL genes among Enterobacteria

\begin{tabular}{|c|c|c|c|}
\hline \multirow{2}{*}{ Types of ESBL genes } & \multicolumn{3}{|c|}{ ESBL Producers } \\
\cline { 2 - 4 } & $\begin{array}{c}\boldsymbol{E} . \text { coli } \\
\text { No. }(\%)\end{array}$ & $\begin{array}{c}\text { Citrobacter } \\
\text { No. }(\%)\end{array}$ & $\begin{array}{c}\text { Klebsiella } \\
\text { No. }(\%)\end{array}$ \\
\hline CTX (n=14) & $11(37.93)$ & $1(3.44)$ & $2(6.89)$ \\
\hline SHV (n=02) & $2(6.89)$ & Nil & Nil \\
\hline TEM (n=01) & $1(3.44)$ & Nil & Nil \\
\hline CTX and TEM (n=06) & $5(17.24 \%)$ & $1(3.44)$ & Nil \\
\hline CTX and SHV (n=03) & $1(3.44)$ & $2(6.89)$ & Nil \\
\hline TEM and SHV (n=02) & $2(6.89)$ & Nil & Nil \\
\hline $\begin{array}{c}\text { CTX,TEM and SHV } \\
(\mathbf{n}=\mathbf{0 1})\end{array}$ & $1(3.44)$ & Nil & Nil \\
\hline Total ESBL isolates= 29 & $\mathbf{2 3 ( 7 9 . 3 1 )}$ & $\mathbf{4 ( 1 3 . 7 9 )}$ & $\mathbf{2 ( 6 . 8 9 )}$ \\
\hline
\end{tabular}




\section{Figures}

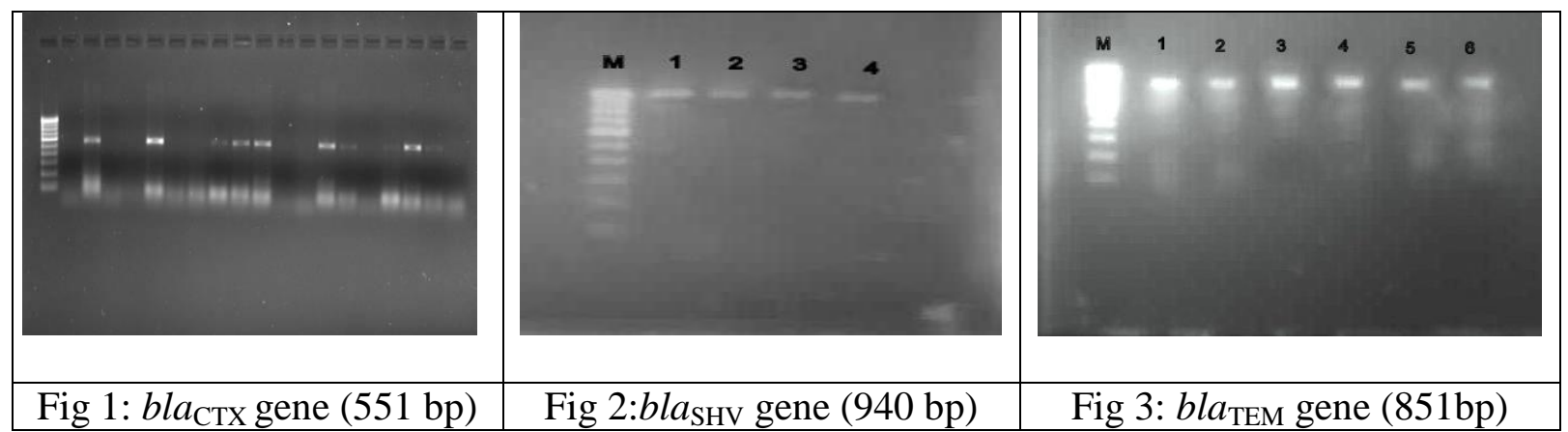

In India, there are several reports suggesting large percentage of enterobacteria to be resistant to third generation cephalosporins with predominance of $b l a_{\mathrm{CTX}}$ gene (Shukla $e t$ al., 2004; Grover et al., 2006; Kumar et al., 2006). This widespread occurrence of ESBLproducing Enterobacteria suggests that the community could act as a reservoir and that food could contribute to the spread of these strains. The present study reveals that ESBLproducing E. coli, Citrobacter and Klebsiella spp. can be transmitted by meat as well as milk. The increasing prevalence of resistance in the isolates from animal origin may have important therapeutic implications, therefore continuous monitoring of ESBL-producing enterobacteria is required at animals, human and environment interface.

\section{Acknowledgement}

The author is thankful to College of Veterinary Sciences and A.H., N.D. University of Agriculture and Technology, Kumarganj, Faizabad (U.P.) for providing facilities to conduct the experiment.

\section{References}

Bush, K., Jacoby, G.A. and Medeiros, A.A. 1995. A functional classification scheme for beta-lactamases and its correlation with molecular structure. Antimicrob. Agents Chemother.
39(6):1211-1233.

CLSI. 2009. Performance Standards for Antimicrobial Disk Susceptibility Tests: Approved standards- Tenth edition. CLSI Waine, Pennsylvania. USA.

Coque, T. M., Baquero F. and Canton, R. 2008. Increasing prevalence of ESBLproducing Enterobacteriaceae in Europe. Euro. Surveill. 13(47):1-11.

Cruickshank, R., Duguid, J.P., Marmion, B.P. and Ewing, W.H. 1975. Identification of Enterobacteriacae, 3rd ed. Burge Publishing co. Atlanta, Georgia, U.S.A., pp 152-154.

Duan, R.S., Homas, H.C. and Samson, S.Y. 2006. Escherichia coli producing CTX$\mathrm{M}$ beta-lactamases in food animals in Hong Kong. Microb. Drug. Resist. 12: 145-148.

Edwards, P.R. and Ewing, W.H. 1972. Identification of Enterobacteriaceae, $3^{\text {rd }}$ ed., (Minneapolis: Burges Publishing Co.). Georgia, U.S.A. 290.

Fadel, H.M. and Ismail, J. 2009. Prevalence and significance of staphylococcus aureus and Enterobacteriaceae species in selected dairy products and handlers. Int. J. of Dairy Sci. 4(3): 100-108.

Franco, S., Murphy, M. M., Li, G., Borjeson, T., Boboila C. and Alt, F.W. 2008. DNA-PKcs and Artemis function in the end-joining phase of immunoglobulin heavy chain class switch recombination. J. Exp. Med. 205: 557-564. 
Geser, N., Stephan, R., Korczak, B.M., Beutin, L. and Hachler, H. 2012. Molecular identification of extendedspectrum- $\beta$-lactamase genes from Enterobacteriaceae isolated from healthy human carriers in Switzerland. Antimicrob. Agents Chemother. 56:1609-1612.

Grover, S.S., Sharma, M., Chattopadhya, D., Kapoor, H., Pasha, S.T. and Singh, G. 2006. Phenotypic and genotypic detection of ESBL mediated cephalosporin resistance in Klebsiella pneumoniae: emergence of high resistance against cefepime, the fourth generation cephalosporin. J. Infect. 53: 279-288.

Gundogan, N. and Avci, E. 2013. Prevalence and antibiotic resistance of extended spectrum beta-lactamase (ESBL) producing Escherichia coli and Klebsiella species isolated from foods ofanimal origin in Turkey. Afr J Microbiol Res. 7:4059-4064.

Gundogan, N. and Yakar, U. 2007. Siderophore production, serum resistance, hemolytic activity and extended spectrum beta lactamaseproducing Klebsiella species isolated from milk and milk products. J Food Saf. 3:251-260.

Gundogan, N., Citak, S. and Yalcin, E. 2011. Virulence properties of extended spectrum beta-lactamase producing Klebsiella species in meat samples. J Food Prot. 74:559-564.

Haryani, Y., Noorzaleha, A.S., Fatimah, A.B., Noorjahan, B.A., Patrick, G.B., Shamsinar, A.T., Laila, R.A.S. and Son, R. 2007. Incidence of Klebsiella pneumonia in street foods sold in Malaysia and their characterization by antibiotic resistance, plasmid profiling, and RAPD-PCR analysis. Food Cont. 18:847-853

Hiroi, M., Yamazaki, F., Harada, T.,
Takahashi, N., Iida, N., Noda, Y., Yagi, M., Nishio, T., Kanda, T. and Kawamori, F. 2012. Prevalence of extended-spectrum b-lactamaseproducing Escherichia coli and Klebsiella pneumoniae in foodproducing animals. J Vet Med Sci. 74:189-195.

Jacoby, G. A. and Medeiros, A. A. 1991. More extended-spectrum betalactamases. Antimicrob Agents Chemother. 35:1697 -1704.

Jensen, L.B., Hasman, H., Agerso, Y., Emborg, H.D. and Aarestrup, F.M. 2006. First description of oxyiminocephalosporin-resistant, ESBL-carrying Escherichia coli isolated from meat sold in Denmark. J. Antimicrob. Chemother. 57:793-794.

Khan, I., Shah, A.M., Mehmood, F.S., Saeed, A., and Sualeh, M. 2015. Determination and identification of Enterobacteriaceae in Street Vended Foods in Karachi, Pakistan. Pak. J. of Nutrition. 14 (4): 225-228.

Kim, J., Lim, Y.M. and Rheem, I. 2005. CTX-M and SHV-12 betalactamases are the most common extended-spectrum enzymes in clinical isolates of Escherichia coli and Klebsiella pneumoniae collected from 3 university hospitals within Korea. FEMS Microbiol Lett. 245: 93-98.

Kolar, M., Bardon, J., Chroma, M., Hricova, K., Stosova, T., Sauer, P. and Koukalova, D. 2010. ESBL and AmpC beta-lactamase-producing

Enterobacteriaceae in poultry. Czech Republic. Veterinarni Medicina. 55:119-124

Kumar, H., Sharma, D., Palaha, R., Sharma, P. and Sonkusale, S. 2011. Isolation of Escherichia coli from indigenous sweet milk products in relation to public health sold at sweet- meat shops of Jalandhar city, India. Internet $\mathbf{J}$ of Food 
Safety. 13: 332-335.

Le,H.V., Kawahara'R., Khong, D.T., Tran, H.T., Pham, K.N., and Jinnai, K. 2015. Widespread dissemination of extendedspectrum $\quad \beta$-lactamase-producing, multidrug-resistant Escherichia coli in livestock and fishery products in Vietnam. Int $\mathbf{J}$ of Food Contamination. $2: 17$.

Melzera, M. and Petersen, I. 2007. Mortality following bacteraemic infection caused by extended spectrum beta-lactamase (ESBL) producing E. coli compared to non-ESBL producing $E$. coli. J Infect. 55:254-259.38.

Mesa, R.J., Blanc, V. and Blanch, A.R. 2006. Extended-spectrum beta-lactamaseproducing Enterobacteriaceae in different environments (humans, food, animal farms and sewage). J Antimicrob Chemother. 58(1): 211-215.

Overdevest, I., Willemsen, I., Rijnsburger, M., Eustace, A., Xu, L., Hawkey, P., Heck, M., Savelkoul, P., Vandenbroucke-Grauls, C., van der Zwaluw, K., Huijsdens, X., Kluytmans, J. 2011. Extended-spectrum $\beta$-lactamase genes of Escherichia coli in chicken meat and humans, the Netherlands. Em. Infect. Dis. 17:1216-1222.

Paterson, D.L. and Bonomo, R.A. 2005. Extended-spectrum beta-lactamases: a clinical update. Clin Microbiol Rev. 18:
657-686.

Saikia, P. and Joshi, S.R. 2010. Retail market poultry meats of North-East India-A microbiological survey for pathogenic contaminants. Res J of Microbiol. 5(1): 36-43.

Shahid, M., Malik, A., Adil, M., Jahan, N. and Malik, R. 2009. Comparison of beta-lactamase genes in clinical and food bacterial isolates in India. J Infect Dev Ctries. 3(8):593-598.

Shukla, I., Tiwari, R. and Agrawal, M. 2004. Prevalance of extended spectrumlactamase producing Klebsiella pneumoniae in a tertiary care hospital. Indian J Med Microbiol. 22:87- 91.

Tekiner, I.H. and Ozpınar, H. 2015. Occurrence and characteristics of extended spectrum beta-lactamasesproducing Enterobacteriaceae from foods of animal origin. Braz $\mathbf{J}$ Microbiol. 47(2): 444-451.

Tham,J., Melander, E., Walder, M. and Odenholt, I. 2012. Prevalence of extended-spectrum beta-lactamaseproducing bacteria in food. Inf and Drug Resist. 5:143-147.

Yusha'u, M., Abubakar, H. M. and Kawo, A. H. 2010. Commercial food as a potential source of Extended spectrum beta lactamases in kanon. $\mathbf{J}$ of Pharmac and Appl Sci. 1(1): 59-62.

\section{How to cite this article:}

Akanksha Yadav, Namita Joshi and Joshi, R.K. 2019. Occurrence of Extended-Spectrum BetaLactamases (ESBLS) Producing Enterobacteria in Animal Products and their Environment. Int.J.Curr.Microbiol.App.Sci. 8(05): 2255-2264. doi: https://doi.org/10.20546/ijcmas.2019.805.265 